\title{
Study on use of Saw Dust Ash as Replacement of Cement in Concrete
}

\author{
Mohd Imran Lone Alise Mapnoo ${ }^{1}$, Adil Masood ${ }^{2}$ \\ ${ }^{1}$ Student, ${ }^{2}$ Assistant Professor \\ Al-falah University, Faridabad, Haryana, India
}

\section{ABSTRACT}

Scientists, Engineers and Technologists are continuously on the lookout for materials which can be used as substitutes for conventional materials or which possess such properties that would enable their use for new designs and innovations. Applications of Concrete alternative materials fall under the first category. The raw materials for making cement and aggregates are essentially limitless, since practically all of earth's crust can be utilized, if associated costs and energy requirements can be complied with. This course of action cannot be taken as there are other constraints that merit closer examination. The successful utilization of a waste material depends on its use being economically competitive with the alternate natural material. These costs are primarily made up of handling, processing and transportation. The waste materials that can be used in concrete are countless in number. The form in which they are used is wide and varied- they may be used as binder, as a partial replacement of conventional Portland cement or directly as aggregates in their natural or processed states. The stability and durability of products made of concrete using waste material over the expected life span is of utmost importance, particularly in relation to building and structural applications. Keeping all these considerations in mind and taking note of all required standard specifications, wherever possible. our Project aims at creating the confidence of using Waste saw dust ash as high value product in concrete. The project will explore several relevant issues that will be vital when using saw dust ash in concrete. The project will also examine ways to optimize the use of material so that they will offer maximum benefits to the concrete. The project will work out in making concrete industry sustainable. The basic necessity of man after food and water is shelt.
Keywords: saw dust, saw dust ash, workability, mix design, compressive strength

\section{INTRODUCTION}

Concrete is defined as any solid mass made with the use of a cementing medium; the ingredients generally comprise sand, gravel, cement and water. That the mixture together of such disparate and discrete materials can result in a solid mass (of any desired shape), with well-defined properties, is a wonder in itself. The word concrete comes from the Latin word "concretus" (meaning compact or condensed), the past participate of "con Cresco", from "com-" (together) and "Cresco" (to grow).

Concrete has been in use as a building material for more than a hundred and fifty years. Its success and popularity may be largely attributed to

> Durability under hostile environments (including resistance to water),

Ease with which it can be cast into a variety of shapes and sizes, and

Its relative economy and easy availability

Concrete is remarkably strong in compression, but it is equally remarkably weak in tension. Its tensile 'strength' is approximately one-tenth of its compressive 'strength'. Hence the use of plain concrete as a

Structural material is limited to situations where significant tensile stresses and strains do not develop, as in hallow (or solid) block wall constructions, small pedestals and 'mass concrete' applications (in dams,) etc. Modern concretes preserve these ancient virtues while greatly extending the range of technically achievable goals. 
Concrete is used in many different structures such as dam, pavement, building frame or bridge. Also, it is the most widely used material in the world, far exceeding other materials. Its worldwide production exceeds that of steel by a factor of 10 in tonnage and by more than a factor 30 in volume. The present consumption of concrete is over 10 billon tons a year, that is, each person on earth consumes more than 1.7 ton of concrete per year. It is more than 10 times of the consumption by weight of steel.

\section{Scope of current study: -}

As discussed earlier cement concrete consumes very high amount of virgin materials and it also suffers from some serious problems when exposed to the environment, like sulphate attack. Partial replacement of cement by waste saw dust ash can overcome these problems and yield high performance concrete. The saw dust ash cement on hydration produces practically no $\mathrm{Ca}(\mathrm{OH}) 2$ \& hence is superior to Portland cement. Since most of the research work has not been carried out on Saw dust ash, hence there is a scope of studying the behavior of concrete involving the use of varied percentages of waste saw dust ash.

\section{Objectives of current study: -}

$>\quad$ To explore and assess the possibility of using waste saw dust ash in concrete in terms of its strength.

$>\quad$ Recover a wood by product through beneficial use when incorporated into concrete.

$>\quad$ To assess the durability of concrete mix.

$>\quad$ To Assess the Compressive strength of concrete mix

\section{DATA COLLECTION}

\subsection{Tests on fine aggregates:-}

4.1.1 Sieve analysis of fine aggregate:

Source: - River sand.

Weight of sample: - 1000gm.

Table-4.1 Sieve analysis of fine aggregates

\begin{tabular}{|c|c|c|c|c|}
\hline $\begin{array}{c}\text { S. } \\
\text { No. }\end{array}$ & $\begin{array}{c}\text { IS Sieve } \\
\text { size }\end{array}$ & $\begin{array}{c}\text { Weight retained } \\
(\text { gm })\end{array}$ & $\begin{array}{c}\text { Cumulative weight } \\
\text { retained(gm) }\end{array}$ & $\begin{array}{c}\text { Cumulative\% } \\
\text { age Wt Retained. }\end{array}$ \\
\hline 1. & $4.75 \mathrm{~mm}$ & 0 & 0 & 0 \\
\hline 2. & $2.36 \mathrm{~mm}$ & 10 & 10 & 1 \\
\hline 3. & $1.18 \mathrm{~mm}$ & 25 & 35 & 3.5 \\
\hline 4. & $600 \mu$ & 115 & 150 & 81.7 \\
\hline 5. & $300 \mu$ & 667 & 817 & 98.1 \\
\hline 6. & $150 \mu$ & 164 & 981 & 99.5 \\
\hline 7. & Pan & 14 & 995 & \\
\hline
\end{tabular}

Result: -

Fineness Modulus $=\sum$ Cumulative \%age Wt retained $/ 100$

$$
=298.8 / 100=2.98
$$

Sand is coarse.

As per IS 383-1970, the sand falls in Zone III. 
International Journal of Trend in Scientific Research and Development (IJTSRD) ISSN: 2456-6470

Table-4.2 Specific gravity test of fine aggregates

\begin{tabular}{|c|c|c|c|c|c|}
\hline $\begin{array}{c}\text { S } \\
\text { No. }\end{array}$ & $\begin{array}{l}\text { Wt of density } \\
\text { bottle W1 } \\
\text { (gm) }\end{array}$ & $\begin{array}{c}\text { Wt of bottle \& } \\
\text { aggregate W2 } \\
\text { (gm) }\end{array}$ & $\begin{array}{l}\text { Wt of bottle }+ \\
\text { aggregate+ water } \\
\text { W3 (gm) }\end{array}$ & $\begin{array}{c}\text { Wt of bottle } \\
+ \text { water } \\
\text { W4(gm) }\end{array}$ & $\begin{array}{l}\text { Sp. gravity = } \\
(\text { W2-W1) /[(W2- } \\
\text { W1) (W3-W4)] }\end{array}$ \\
\hline 1. & 681.1 & 820.6 & 1635.5 & 1549 & 2.63 \\
\hline 2. & 681.1 & 825.5 & 1644.2 & 1549 & 2.50 \\
\hline 3. & 681.1 & 840.5 & 1650 & 1549 & 2.68 \\
\hline
\end{tabular}

Average value of specific gravity $=2.6$.

4.1.3 Tests on cement: -

Table-4.3 Standard consistency test

\begin{tabular}{|c|c|c|c|c|c|c|}
\hline $\begin{array}{c}\text { S } \\
\text { No. }\end{array}$ & $\begin{array}{l}\text { Wt. of } \\
\text { cement }(\mathrm{g})\end{array}$ & $\begin{array}{c}\text { Wt of water } \\
\text { added }\end{array}$ & $\begin{array}{c}\% \text { age of water added } \\
\text { by wt. of cement }\end{array}$ & $\begin{array}{l}\text { Penetration } \\
\quad(\mathrm{mm})\end{array}$ & $\begin{array}{c}\text { Standard } \\
\text { Consistency }\end{array}$ & $\begin{array}{l}\text { Permissible value } \\
\text { as per IS } 4031(\%)\end{array}$ \\
\hline 1. & 400 & 116 & 29 & 20 & \multirow{3}{*}{$\begin{array}{l}\text { At } 31 \% \text { by } \\
\text { weight of } \\
\text { cement }\end{array}$} & \multirow{3}{*}{$\begin{array}{c}\text { Should be about } \\
30 \% \text { by wt of } \\
\text { cement }\end{array}$} \\
\hline 2. & 400 & 119.58 & 30 & 30 & & \\
\hline 3. & 400 & 124 & 31 & 33 & & \\
\hline
\end{tabular}

4.1.4 Setting time test: -

Table-4.4 Setting time test of cement

\begin{tabular}{|l|l|l|l|l|l|l|}
\hline $\begin{array}{l}\text { Wt of water } \\
\text { added(0.85P) } \\
\text { gm }\end{array}$ & $\begin{array}{l}\text { Penetrati } \\
\text { on (mm) }\end{array}$ & $\begin{array}{l}\text { Initial } \\
\text { Setting time }\end{array}$ & $\begin{array}{l}\text { Permissibl } \\
\text { e value }\end{array}$ & $\begin{array}{l}\text { Final } \\
\text { Setting } \\
\text { time }\end{array}$ & $\begin{array}{l}\text { Permissible value } \\
\text { as per IS4031 (\%) }\end{array}$ & Remarks \\
\hline 118 & 35 & $\begin{array}{l}1 \text { hrs } \\
\text { min }\end{array}$ & $\begin{array}{l}\text { Not less } \\
\text { than30 min }\end{array}$ & $\begin{array}{l}5 \text { hrs and } \\
50 \mathrm{~min} .\end{array}$ & $\begin{array}{l}\text { Not more than } 10 \\
\text { hrs. }\end{array}$ & $\begin{array}{l}\text { Satisfying } \\
\text { the criteria }\end{array}$ \\
\hline
\end{tabular}

Size: - Max $20 \mathrm{~mm}$

Weight of sample $=3000 \mathrm{gms}$

Table-4.5 Sieve analysis of coarse aggregates

\begin{tabular}{|c|c|c|c|c|c|c|}
\hline $\begin{array}{l}\text { S. } \\
\text { No }\end{array}$ & $\begin{array}{l}\text { IS Sieve } \\
\text { Size }(\mathrm{mm})\end{array}$ & $\begin{array}{l}\text { Wt. retained } \\
\text { (gm) }\end{array}$ & $\begin{array}{l}\% \text { age } w t \\
\text { retained }\end{array}$ & $\begin{array}{l}\text { Cumulative\% } \\
\text { age wt retained }\end{array}$ & $\begin{array}{l}\text { \%age wt } \\
\text { passing }\end{array}$ & $\begin{array}{l}\text { Grading limits single } \\
\text { sized } 20 \mathrm{~mm} \text { aggregate }\end{array}$ \\
\hline 1. & 40 & 0 & $0 \mathrm{C}$ & $2 / 560.170$ & 100 & \multirow{6}{*}{$\begin{array}{c}\text { Not conforming to } \\
\text { grading limits as per IS } \\
383-1970\end{array}$} \\
\hline 2. & 20 & 150 & 5 & 5 & 95 & \\
\hline 3. & 10 & 2832 & 94.1 & 99.1 & 0.9 & \\
\hline 4. & 4.75 & 27 & 0.9 & 100 & 0 & \\
\hline 5. & 2.36 & - & - & $+\quad-$ & - & \\
\hline 6. & Pan & - & $n_{-}$ & -1 & $3-$ & \\
\hline
\end{tabular}

FINENESS MODULUS $=\sum$ Cumulative \%age wt retained $/ 100=2.04$

Table-4.6 Specific gravity test of coarse aggregate

\begin{tabular}{|l|l|l|l|l|l|}
\hline $\begin{array}{l}\text { S } \\
\text { No. }\end{array}$ & $\begin{array}{l}\text { Wt of density } \\
\text { bottle } \\
\text { W1 (gm) }\end{array}$ & $\begin{array}{l}\text { Wt of bottle } \\
\text { \& aggregate } \\
\text { W2 (gm) }\end{array}$ & $\begin{array}{l}\text { Wt of bottle + } \\
\text { aggregate +water } \\
\text { W3(gm) }\end{array}$ & $\begin{array}{l}\text { Wt of bottle + } \\
\text { water W4(gm) }\end{array}$ & $\begin{array}{l}\text { Sp. gravity }=\text { W2 -W1 } \\
/[(W 2-W 1)-(W 3-W 4)]\end{array}$ \\
\hline 1. & 680.5 & 1000.5 & 1784 & 1583.5 & 2.67 \\
\hline 2. & 680.5 & 1030.5 & 1804.5 & 1583.5 & 2.71 \\
\hline 3. & 680.5 & 1040.5 & 1810 & 1583.5 & 2.7 \\
\hline
\end{tabular}

Average value of specific gravity $=2.7$. 


\section{Result and Analysis}

As per our objectives we were able to develop Design mix with Saw Dust Ash as partial replacement of cement on the percentage of $8 \%, 16 \%$ and $24 \%$.A number of parameters like compressive strength,water absortion,overall weight of concrete,workability were determined and presented as follows: -

Concrete mix design (grade M-25)

The mix used in the trials is the design mix M 25 . This is a reference mix used. The normal concrete cubes have been casted utilizing the design parameters obtained for this mix. The design method used is the IS 10262-1982. Thus, the design parameters are same for every concrete and only the respective replacements are made accordingly from the already obtained design parameters.

\section{(A) Design stipulations}

1. Characteristic strength at 28 days $25 \mathrm{MPa}$.

2. Maximum size of aggregate $20 \mathrm{~mm}$.

3. Degree of workability 0.75 C.F.

4. Type of exposure Moderate.

\section{(B)Test data of materials}

1. Specific gravity of cement 3.16.

2. Specific gravity of coarse aggregate 2.7 .

3. Specific gravity of fine aggregate 2.62 .

4. Zone factor for sand III

Target mean strength $=\mathrm{fck}+1.65 * 4=31.6 \mathrm{~N} / \mathrm{mm}^{3}$

\subsection{Normal concrete M25}

The various design parameters are:

Water cement ratio $=0.45$

Compaction factor $=0.80$

Cement content $=425.73 \mathrm{~kg} / \mathrm{m}^{3}$

Fine aggregate $=619.64 \mathrm{~kg} / \mathrm{m}^{3}$

Coarse aggregate $=1163.64 \mathrm{~kg} / \mathrm{m}^{3}$

Water content $=191.58 \mathrm{~kg} / \mathrm{m}^{3}$

Ratio $=$ C: W: CA: FA

$=1: 0.45: 2.73: 1.45$

\subsubsection{Casting}

The concrete was mixed by the Electric Mixer, hand mixing and cubes were filled and vibrated on the vibrating table. The cubes used as molds are of dimensions $150 \mathrm{~mm} \times 150 \mathrm{~mm} \times 150 \mathrm{~mm}$. The materials were thoroughly mixed with the spades on a clean
CGI sheet. Then water was mixed to the materials. The cubes were filled and vibrated on the mechanical vibrating table. Then they were allowed to set for 24 hours before the molds could be removed. The cubical molds were cleaned and oiled before pouring concrete mix in them.

\section{Slump Test}

Slump test was conducted, and slump values have been obtained in observation table-

\subsubsection{Curing: -}

The cubes have been cured after removing the moulds after 24 hours. Curing has been done by keeping the specimens immersed in water for a period of 6 days for the 7 day test and 26 days for the 28 day test from the date of casting.

The cubes have been tested for the compressive strength at 7 and 28 days respectively under a compressive testing machine. The specimens after proper curing for the required period were tested. The observations seen in the fresh as well as in post hardening test are given in the table below. Three cubes were tested, and then average value was taken.

Date of casting - 18/07/18.

Date on $7^{\text {th }}$ day testing $-25 / 07 / 18$.

Date on $28^{\text {th }}$ day testing $-16 / 08 / 18$.

Table-5.1 Compressive strength test for normal M 25 mix.

\begin{tabular}{|c|c|c|c|c|c|}
\hline $\begin{array}{l}\text { C } \\
\mathbf{u} \\
\mathbf{b} \\
\mathbf{e}\end{array}$ & \begin{tabular}{|l|} 
Slu \\
mp \\
$(\mathrm{m}$ \\
$\mathrm{m})$
\end{tabular} & $\begin{array}{l}\text { Load } \\
\text { taken } \\
\text { @ } \\
\text { 7days } \\
\text { (KN) }\end{array}$ & $\begin{array}{l}\text { Load } \\
\text { taken } \\
\text { @ 28 } \\
\text { days } \\
\text { (KN) }\end{array}$ & $\begin{array}{l}\text { Compressi } \\
\text { ve } \\
\text { strength } \\
\text { @ } 7 \text { day } \\
\left(\mathrm{N} / \mathrm{mm}^{2}\right)\end{array}$ & $\begin{array}{l}\text { Compres } \\
\text { sive } \\
\text { strength } \\
@ 28 \text { day } \\
\left(\mathbf{N} / \mathrm{mm}^{2}\right)\end{array}$ \\
\hline 1 & 100 & 465 & 630 & 20.66 & 28 \\
\hline 2 & 100 & 448 & 650 & 19.9 & 28.8 \\
\hline 3 & 100 & 452 & 642 & 20 & 28.5 \\
\hline
\end{tabular}

Average compressive strength @ 7 days $=60.56 / 3=\mathbf{2 0 . 1 8} \mathrm{N} / \mathbf{m m}^{2}$.

Average compressive strength @ 28 days $=85.3 / 3=28.43 \mathrm{~N} / \mathrm{mm}^{2}$. 


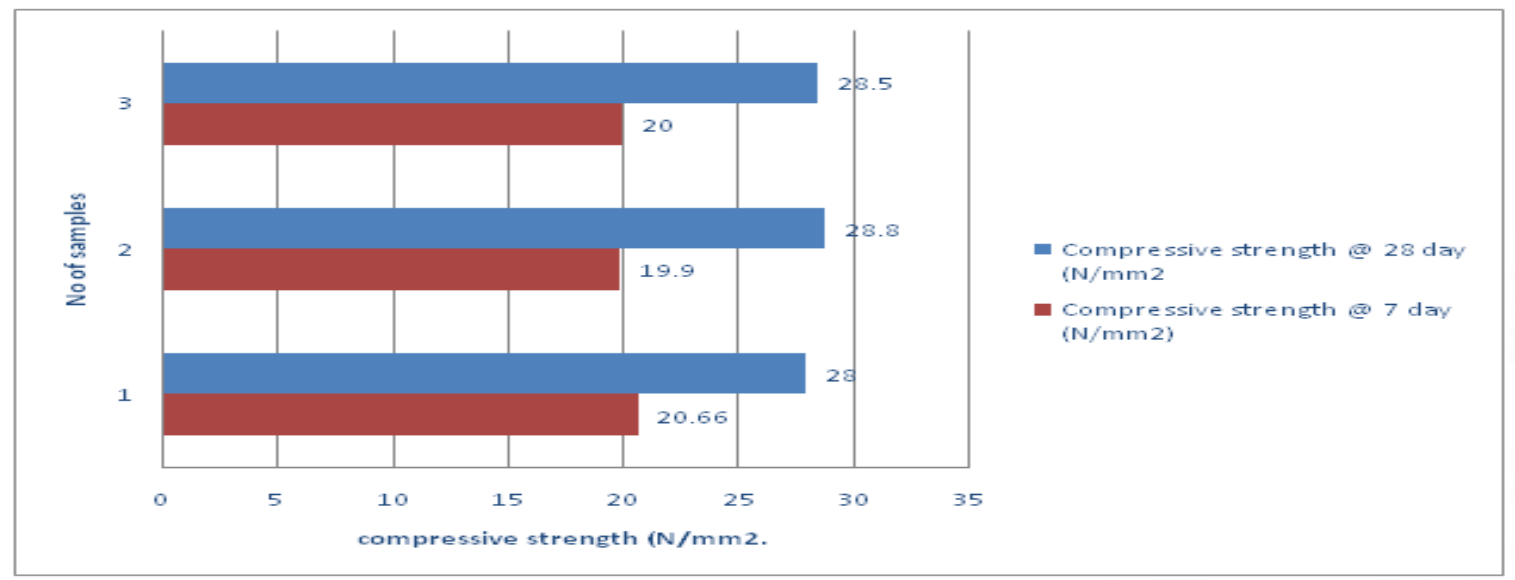

Fig 14 Compressive Strength of M25 for 7 Days and 28 day

\subsubsection{Water absorption test: -}

Average weight of cubes in wet condition $=2166 \mathrm{gm}$. Average weight of cubes in dry condition $=2073 \mathrm{gm}$.

Water absorbed $=2166-2073=93$ gm.

Saw Dust Ash It is a by-product of cutting, grinding, drilling, sanding, or otherwise pulverizing wood with a saw or other tool. It is composed of fine particles of wood. The saw dust used for this project was collected from nearby sawmill. Samples were carefully collected to avoid mixing with sand by collecting the newly produced ones with shovel and packing into bags. The saw dust collected was sundried for 10 days to aid the burning process. The saw dust samples collected were burnt into ashes by open burning at temperature of 200 degree Celsius in a drum. The
Ash was then ground after cooling. . Sawdust ash obtained is sieved through IS sieve of 90 micron and the retained material obtained is used for experimentation purposes. Chemical composition of saw dust is presented in TABLE 1. Fig.1 shows saw dust ash added to cement for blending and Fig. 2 shows sieving of saw dust ash.

A waste material from timber industry having following characteristics

\begin{tabular}{|l|l|}
\hline Oxide & $\%$ (by wt.) \\
\hline $\mathrm{SiO} 2$ & 68.30 \\
\hline $\mathrm{Al} 2 \mathrm{O} 3$ & 3.5 \\
\hline $\mathrm{Fe} 2 \mathrm{O} 3$ & 2.23 \\
\hline $\mathrm{MgO}$ & 5.4 \\
\hline $\mathrm{CaO}$ & 5.0 \\
\hline
\end{tabular}

Table-5.2 Mixture proportions for saw dust ash

\begin{tabular}{|l|l|l|l|l|l|l|l|}
\hline $\begin{array}{l}\text { Waste saw } \\
\text { dust ash \% }\end{array}$ & $\begin{array}{l}\text { w/c } \\
\text { ratio }\end{array}$ & $\begin{array}{l}\text { Water } \\
\left(\mathrm{Kg} / \mathrm{m}^{3}\right)\end{array}$ & $\begin{array}{l}\text { Cement } \\
\left(\mathrm{Kg} / \mathrm{m}^{3}\right)\end{array}$ & $\begin{array}{l}\text { Fine Aggregate } \\
\left(\mathrm{Kg} / \mathrm{m}^{3}\right)\end{array}$ & $\begin{array}{l}\text { Waste saw } \\
\text { dust } \\
\left(\mathrm{Kg} / \mathrm{m}^{3}\right)\end{array}$ & $\begin{array}{l}\text { Coarse } \\
\text { ash } \\
\text { Aggregate } \\
\left(\mathrm{Kg} / \mathbf{m}^{3}\right)\end{array}$ & $\begin{array}{l}\text { Slump } \\
(\mathbf{m m})\end{array}$ \\
\hline 0 & 0.45 & 191.58 & 425.73 & 619.64 & 0.00 & 1163.24 & 75 \\
\hline 8 & 0.45 & 191.58 & 391.73 & 619.64 & 34 & 1163.24 & 66 \\
\hline 16 & 0.45 & 191.58 & 357.73 & 619.64 & 68 & 1163.24 & 70 \\
\hline 24 & 0.45 & 191.58 & 325.71 & 619.64 & 100 & 1163.24 & 72 \\
\hline
\end{tabular}

Table-5.3 Mix design M25 with partial Testing of saw dust ash: replacement of saw dust ash

\begin{tabular}{|l|l|l|l|l|l|}
\hline $\begin{array}{l}\text { \% of } \\
\begin{array}{l}\text { Saw } \\
\text { Dust }\end{array}\end{array}$ & $\begin{array}{l}\text { We Of } \\
\text { Ceme }\end{array}$ & $\begin{array}{l}\text { Wt } \\
\text { Of } \\
\text { C.A }\end{array}$ & $\begin{array}{l}\text { Wt } \\
\text { Of } \\
\text { F.A }\end{array}$ & $\begin{array}{l}\text { Wt Of } \\
\text { Water }\end{array}$ & $\begin{array}{l}\text { Wt Of } \\
\text { Saw Dust } \\
\text { Ash }\end{array}$ \\
\hline $0 \%$ & $8.62 \mathrm{~kg}$ & $\begin{array}{l}23.55 \\
\mathrm{~kg}\end{array}$ & $\begin{array}{l}12.54 \\
\mathrm{~kg}\end{array}$ & $3.87 \mathrm{~kg}$ & Okg \\
\hline $8 \%$ & $8.55 \mathrm{~kg}$ & $\begin{array}{l}23.55 \\
\mathrm{~kg}\end{array}$ & $\begin{array}{l}12.54 \\
\mathrm{~kg}\end{array}$ & $3.87 \mathrm{~kg}$ & $0.7 \mathrm{~kg}$ \\
\hline $16 \%$ & $\begin{array}{l}7.25 \\
\mathrm{~kg}\end{array}$ & $\begin{array}{l}23.55 \\
\mathrm{~kg}\end{array}$ & $\begin{array}{l}12.54 \\
\mathrm{~kg}\end{array}$ & $3.87 \mathrm{~kg}$ & $1.4 \mathrm{~kg}$ \\
\hline $24 \%$ & $5.82 \mathrm{~kg}$ & $\begin{array}{l}23.55 \\
\mathrm{~kg}\end{array}$ & $\begin{array}{l}12.54 \\
\mathrm{~kg}\end{array}$ & $3.87 \mathrm{~kg}$ & $2.8 \mathrm{~kg}$ \\
\hline
\end{tabular}

Cubes were removed from the curing tank. Surface water was wiped off. Cubes were dried for 24 hours. Test cube was placed centrally on the lower plate of CTM. Load was applied without shock and continuously increased at a constant rate. Compressive strength was obtained from the ratio of load applied to that of area under impact (P/A).

\section{Compressive strength $=$ load $/$ Area}

Compressive strength (150 mm cube): - 
International Journal of Trend in Scientific Research and Development (IJTSRD) ISSN: 2456-6470

Table-5.4 Compressive strength test

\begin{tabular}{|c|c|c|c|c|c|c|c|c|}
\hline $\begin{array}{l}\text { s. } \\
\text { no }\end{array}$ & $\begin{array}{l}\text { Saw } \\
\text { dust } \\
\operatorname{ash} \%\end{array}$ & $\begin{array}{l}\text { Date of } \\
\text { casting }\end{array}$ & $\begin{array}{l}\text { Date of } 7 \\
\text { day } \\
\text { testing }\end{array}$ & $\begin{array}{l}\text { Date of } \\
28 \text { day } \\
\text { testing }\end{array}$ & $\begin{array}{l}\text { Avg. } \\
\text { load@7 } \\
\text { day } \\
\text { (KN) }\end{array}$ & $\begin{array}{l}\text { Avg. load } \\
\text { @ } 28 \text { day } \\
(\mathrm{KN})\end{array}$ & $\begin{array}{l}\text { Avg. } \\
\text { compressive } \\
\text { strength @ } 7 \\
\text { days(N/mm²) }\end{array}$ & $\begin{array}{l}\text { Avg. } \\
\text { compressive } \\
\text { strength @ } 28 \\
\text { days(N/mm }\end{array}$ \\
\hline 1 & 0 & $18-07-18$ & $25-07-18$ & $16-08-18$ & 455 & 640.6 & 20.22 & 28.43 \\
\hline 2 & $8 \%$ & $18-07-18$ & $25-07-18$ & $16-08-18$ & 470.33 & 649 & 20.89 & 28.97 \\
\hline 3 & $16 \%$ & 19-07-18 & 26-07-18 & 16-08-18 & 414.6 & 589.3 & 18.36 & 26.17 \\
\hline 4 & $24 \%$ & 19-07-18 & $26-07-18$ & $16-08-18$ & 324.3 & 451 & 14.3 & 20.8 \\
\hline
\end{tabular}

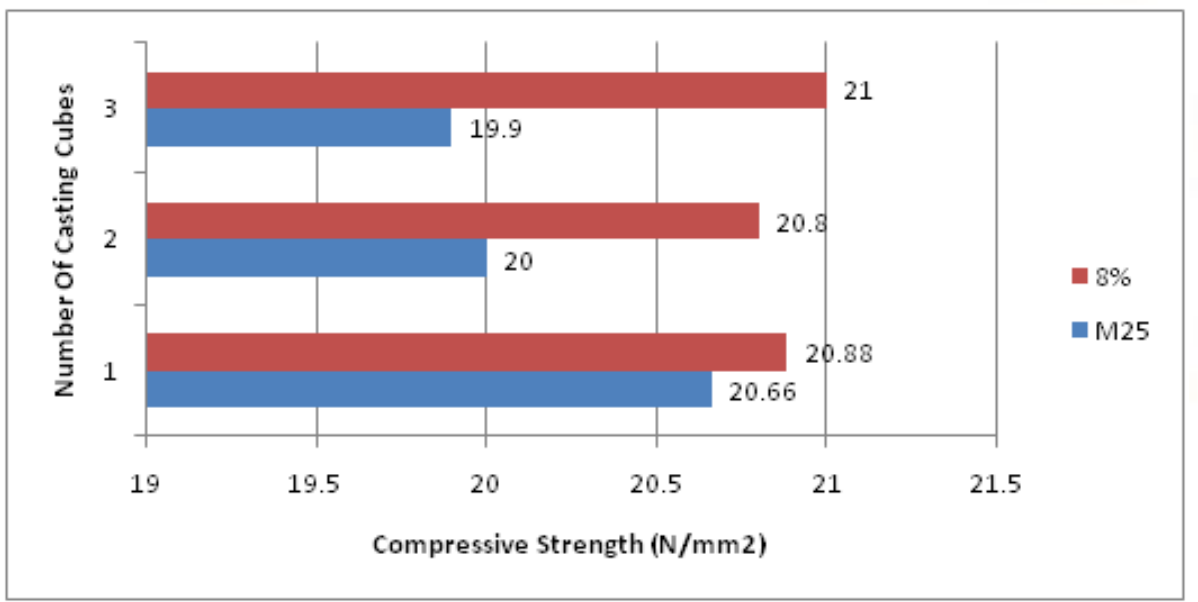

Fig 16: 8\% 7days Compressive Strength (N/mm2)

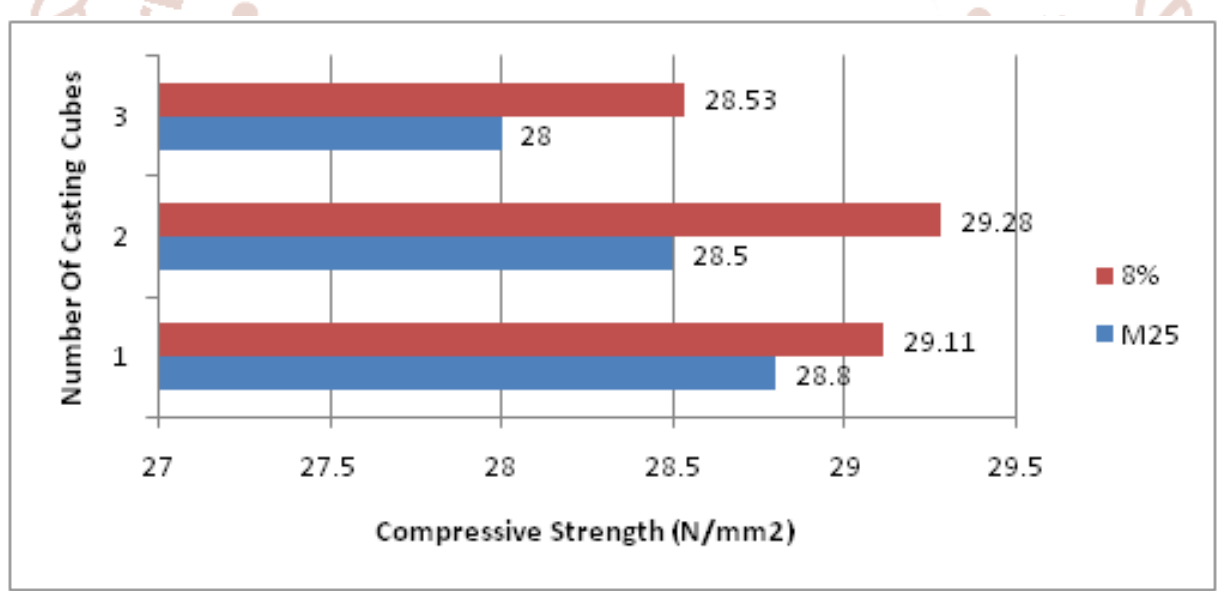

Fig 17: 8\% 28days Compressive Strength (N/mm2)

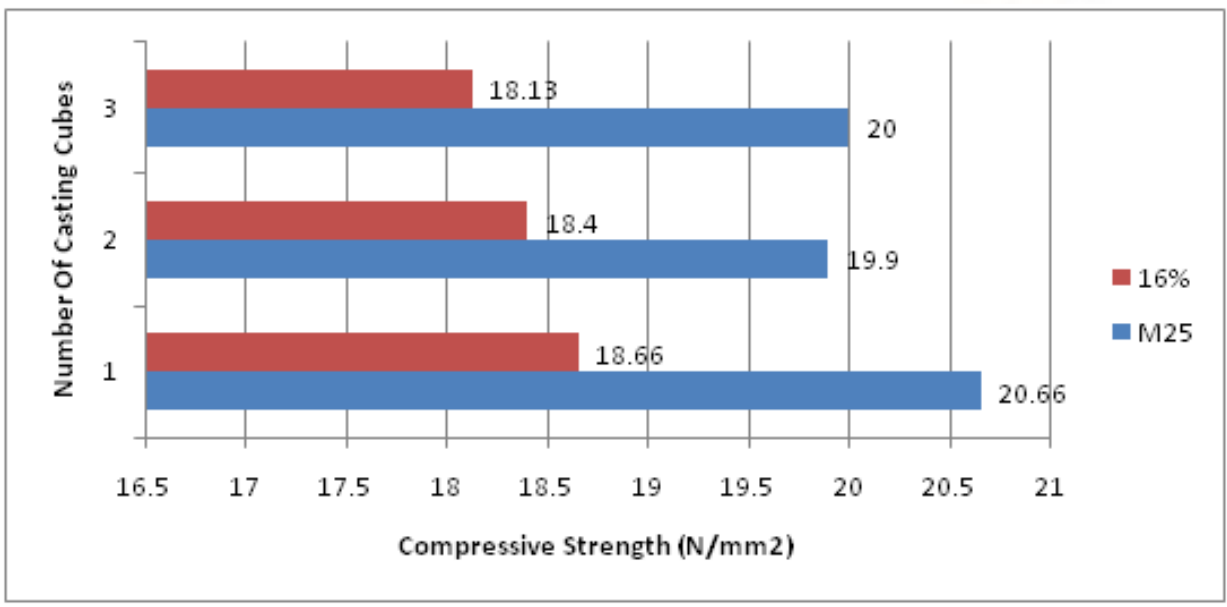

Fig 18: 16\% 7days Compressive Strength (N/mm2) 


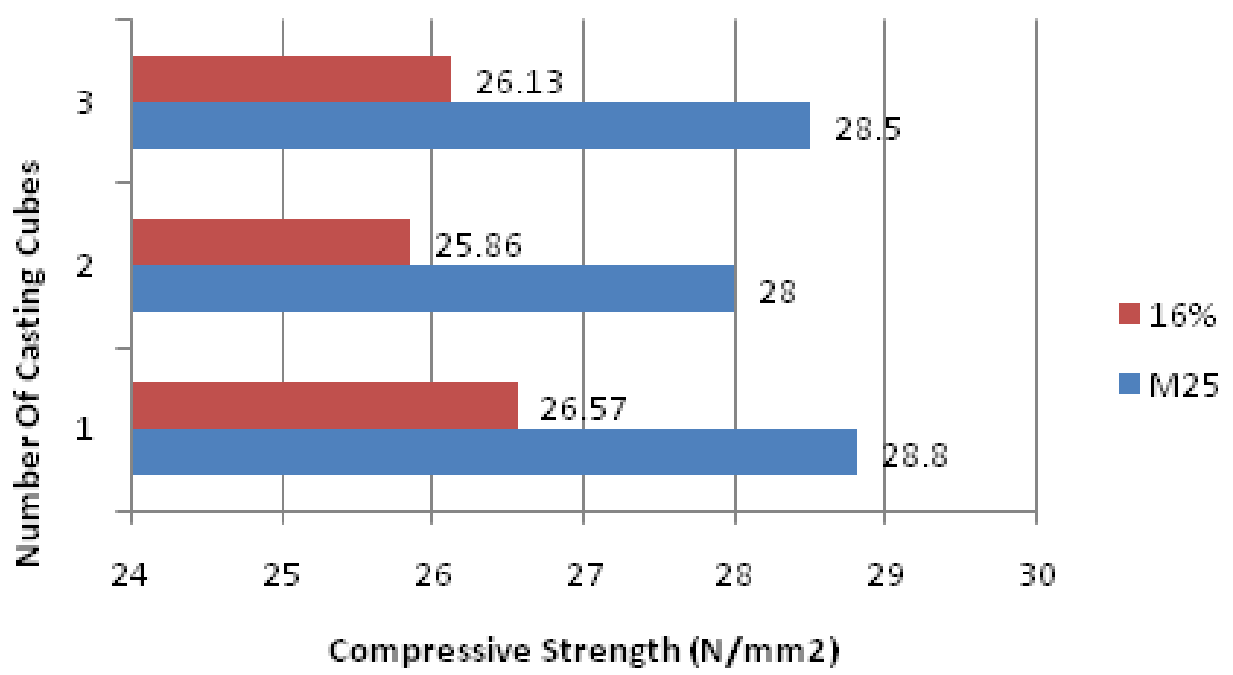

Fig 19: 16\% 28 days Compressive Strength $(\mathrm{N} / \mathrm{mm} 2)$

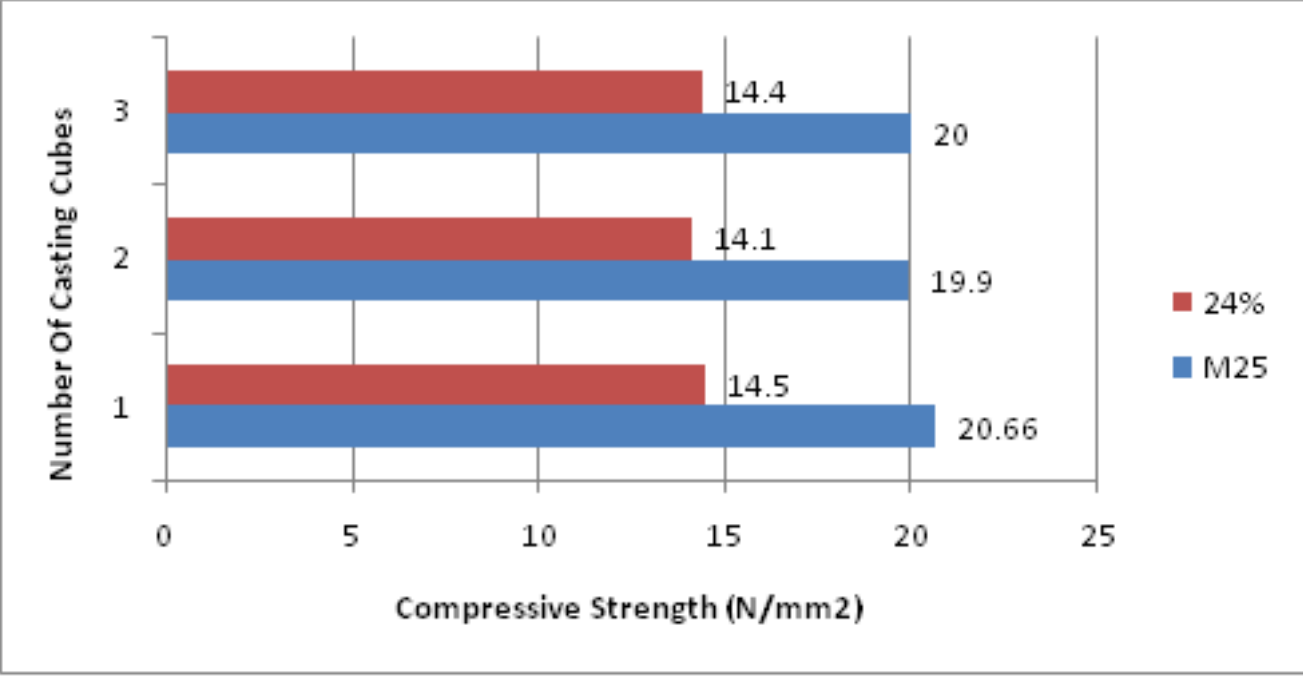

Fig 20: 24 \% 7days Compressive Strength (N/mm2)

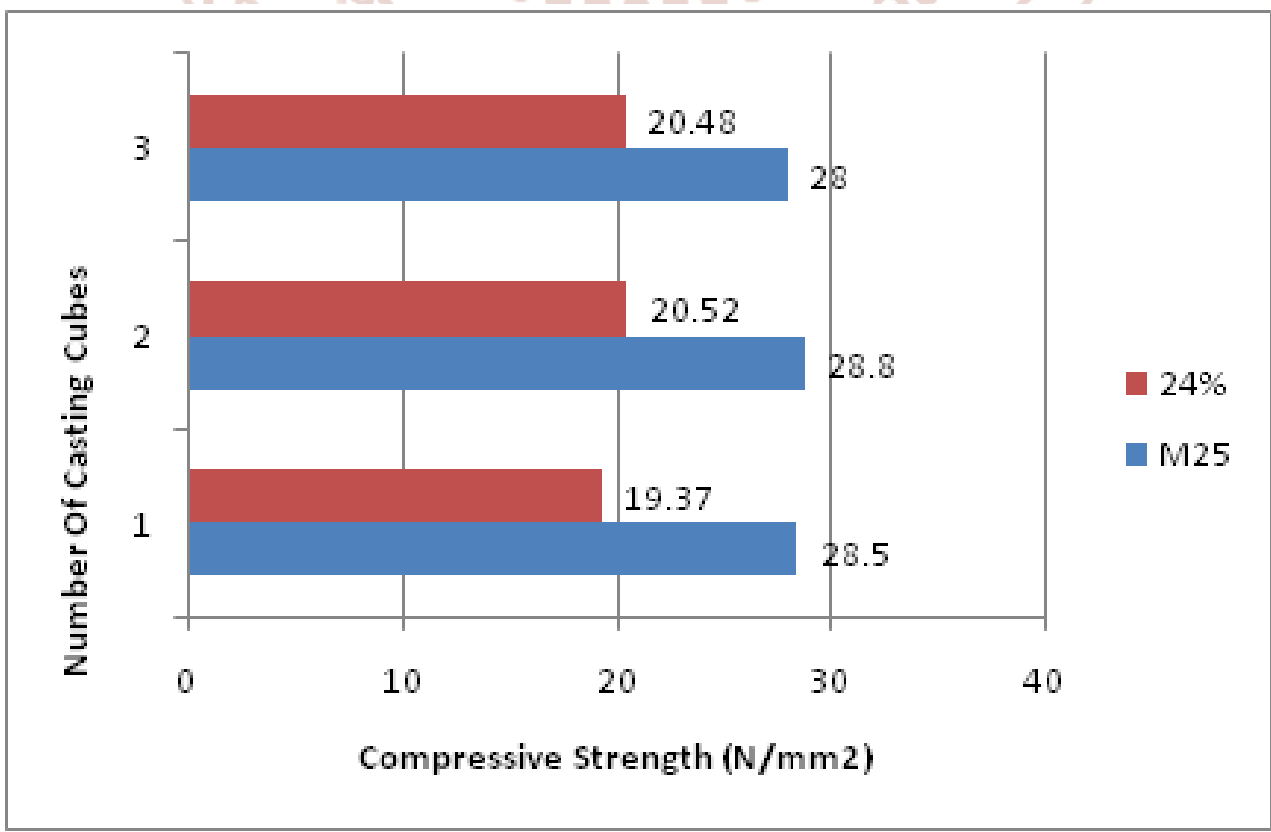

Fig 21: 24\% 28 days Compressive Strength (N/mm2) 
International Journal of Trend in Scientific Research and Development (IJTSRD) ISSN: 2456-6470

Table-5.5 Water absorption test

\begin{tabular}{|c|c|c|c|c|c|c|c|}
\hline $\begin{array}{c}\text { S. } \\
\text { No. }\end{array}$ & $\begin{array}{c}\text { Saw } \\
\text { dust } \\
\text { ash \% }\end{array}$ & $\begin{array}{c}\text { Date of } \\
\text { casting }\end{array}$ & $\begin{array}{c}\text { Date of 28 } \\
\text { day testing }\end{array}$ & $\begin{array}{c}\text { A vg. Dry } \\
\text { weight of cube } \\
\text { (gm) }\end{array}$ & $\begin{array}{c}\text { Avg. Wet weight } \\
\text { of cube (gm) }\end{array}$ & $\begin{array}{c}\text { Water } \\
\text { absorbed } \\
\text { (gm) }\end{array}$ & $\begin{array}{c}\text { Percentage } \\
\text { water } \\
\text { absorption }\end{array}$ \\
\hline 1 & 0 & $18 / 07 / 18$ & $16 / 08 / 18$ & 7318 & 7410 & 92 & 1.09 \\
\hline 2 & $8 \%$ & $18 / 07 / 18$ & $16 / 08 / 18$ & 7426 & 7532 & 106 & 1.25 \\
\hline 3 & $16 \%$ & $19 / 07 / 18$ & $16 / 08 / 18$ & 7300 & 7424 & 124 & 1.55 \\
\hline 4 & $24 \%$ & $19 / 07 / 18$ & $16 / 08 / 18$ & 7113 & 7252 & 139 & 1.71 \\
\hline
\end{tabular}

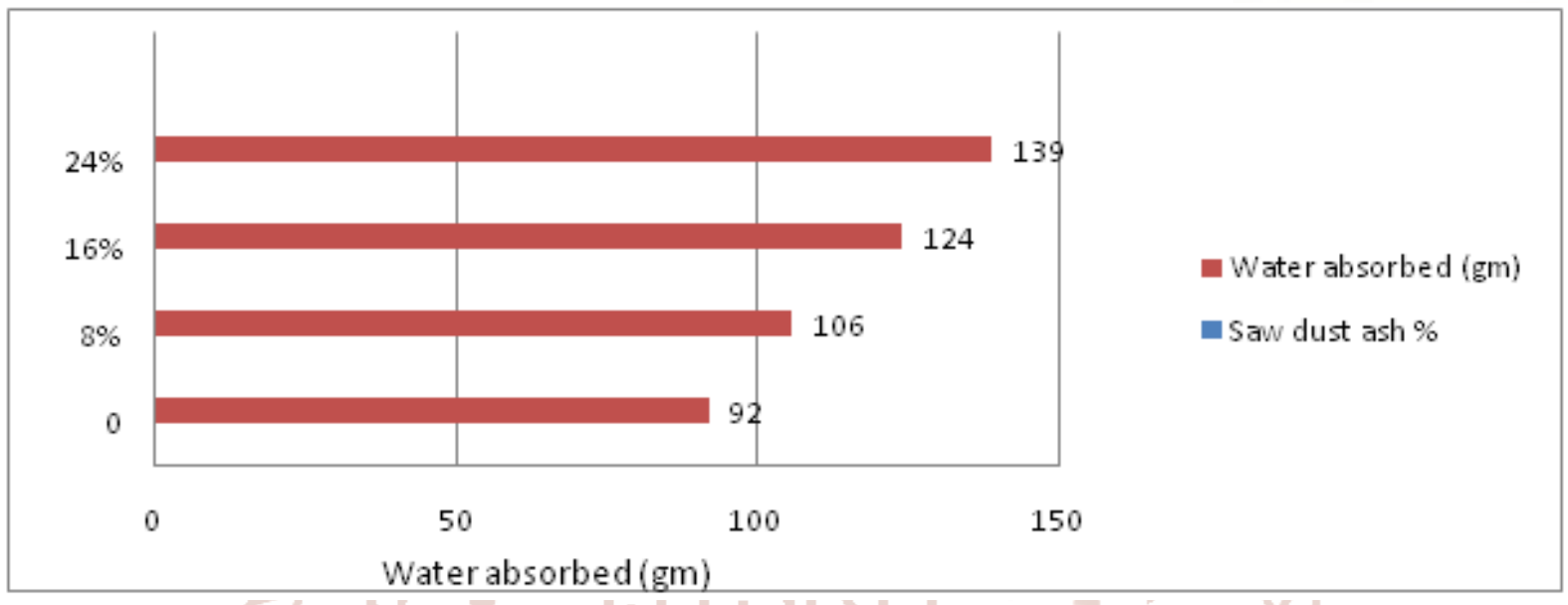

Fig 22:- Water absorption test

\section{Conclusion And Recommendations}

\section{Conclusion: -}

As per the results, we observe that the optimum value for attaining maximum strength is around $8 \%$ as a replacement of saw dust ash and it was also observed that a $16 \%$ partial replacement of saw dust ash attains sufficient strength that falls within the parameter of strength governed by the code (is) and $24 \%$ partial repelcaement of saw dust does not any sufficient strength improvements.

On the basis of results obtained, following recommendations can be made: -

$>$ SDA is a suitable material for use as a pozzolan.

$>$ 2.SDA concrete have lower water requirement which implies the more percentage of SDA makes SDA concrete more workable.

$>$ Saw Dust can prove economical as its available in large quantities.

4Use of saw dust ash in concrete will eradicate the disposal problem of saw dust

5.The compressive strength increases with the curing time and the most recomemded percentage to be used is $8 \%$.

6.The increase of saw dust ash also shows decrese of strength.

$>$ SDA concrete is light in weight so it can also be used in light concreting.

\section{References}

1. Adesanya, D. A. and Raheem, A. A. (2009a), "A study of the workability and compressive strength character istics of corn cob ash blended cement concrete", Construction and Building Materials, Vol. 23, pp. 311-317.

2. Adesanya, D. A. and Raheem, A. A. (2009b), "Development of co rn cob ash blended cement", Construction and Building Materia 1s; Vol. 23, pp. $347-352$.

3. Adesanya, D. A. and Raheem, A. A. (2010), "A study of the permeability and acid attac k of corn cob ash blended cements", Construction and Building Material s, Vol. 24, p p. 403 - 409.

4. Antiohos, S.; Mag anari, K.; Tsimas, S. (2005), "Evaluation of blends of high and low calcium flyashes for $\mathrm{u}$ se as supplementary cementing material s", Cement \& Concrete Composite s, Vol. 27, pp. 349-356.

5. ASTM C 618 (1991), St an dard Specification for Fly Ash and Raw or Cal cined Natural Pozzolan for use as a Mineral Admixtur e in Portland Cement Conc rete, Annual Book o f ASTM Standard s, Philadelphia, USA. Balendr an, R. V. and Martin-Buades , 
6. W. H. (2000), "The influence of high temperature curing on the compressive, tensile and flexural strength of pulverize $d$ fuel ash concrete", Building and Environment, Vol. 35 No.5, pp.415423.

7. BS 1881: Part 102 (1983), Methods f or determination of Sl ump, British Standard Institution, London.BS 1881: Part 103 (1983), Methods for determination of Compacting $\mathrm{f}$ actor, British Standard I institution, London.

8. BS 5224 (1976), S tandard Specification for Masonry Cement, British Standard Institution, London. Cheah, C. B. and Ramli, M. (2011) Properties of High-Strength Concrete u sing a Fine Fly Ash", Cement and Concrete Research, Vol. 28 No.10, p p. 1445-1452.

9. Hossain, K. M. A. (2003), "Blended Cement using Volcanic Ash and P umice", Cement and Concrete Research, Vol. 33, pp. 1601-1605.

10. Hossain, K. M. A. (2005), "Chloride induced corrosion of reinforcement in volcanic ash and pumice based blended concrete", Cement \& Concrete Composites, Vol. 27, pp. 381-39 0.

11. Lee, S.; M oon, H. Y. and Swamy R. N. (2005), "Sulfate attack and role of silica fume in resisting strength loss", Cement \&Concrete Composite s, Vol. 27, pp. 65-76.

12. Raheem, A. A.; Nwakanma, E. O. and Ogunleye , K. O. (2008) “ Engineering Properties of Concrete w ith Palm Kernel She 11 as Fine and Coarse Aggre gates", USEP, Journal of Research Information in Civil Engineering (RICE ), Vol. 5 No.1, pp. 58-70.

13. Raheem, A. A.; Oyebisi , S. O.; Akintayo, S. O. and Oyeniran, M. I. (2010), "Effects of admixtures on the proper ties of corn cob ash cement concrete", Leonardo Electronic Journal of Practices and Technologies, Vol. 16, pp.13-20.

14. Raheem, A. A. and Adesanya, D. A. (2011), "A study of thermal conductivity of corn cob ash blended cement mortar ", The Pacific Journal of Science and Technolog y, Vol.12 No. 2, p p. 106 -111 . 